\title{
Comparison of Short Term Effects of Risperidone and Paliperidone on Serum Prolactin Levels in Female Patients
}

\author{
Yakup Albayrak¹, Cuneyt Unsal' ${ }^{1}$, Murat Beyazyuz², Murat Kuloglu³
}

\section{ÖZET:}

Kadın hastalarda risperidon ve paliperidonun serum prolaktin düzeyleri üzerine kısa dönem etkilerinin karşılaștırılması

\begin{abstract}
Amaç: Hiperprolaktinemi antipsikotik kullanımı ile ilișkili bir yan etkidir. Tüm tipik antipsikotiklerin serum prolaktin düzeylerini yükselttig̃i kabul edilmektedir. Tipik antipsikotiklerle karşıșștıııldı̃ında, atipik antipsikotiklerin serum prolaktin düzeylerini yükseltmeleri açısından daha düșük eg̃ilimleri vardır. Ancak tüm atipik antipsikotiklerin serum prolaktin düzeyi üzerine etkileri her zaman benzer deg̃ildir. Bu çalıșmada iki benzer atipik antipsikotik olan risperidon ve paliperidonun hiperprolaktinemi ve ilişkili belirtiler açısından kısa dönem etkilerini karşılaștırmayı amaçladık. Yöntem: Bu çalışmada, şizofreni ve dig̃er psikotik bozuklar ve iki uçlu bozukluk tanıları ile başvuran; risperidon veya paliperidon ile tedavi edilen kadın hastaların bilgileri taranmıştır. Sosyodemografik ve klinik bilgiler açısından yeterli veriye sahip ve tedavi başlangıcında ve 4 . haftasında serum prolaktin düzeyleri açısından taranmış hastalar çalıșmaya dahil edildi.
\end{abstract}

Sonuçlar: Kırk iki hasta risperidon ile ve 36 hasta paliperidon ile tedavi edilmiști. Gruplar sosyodemografik deg̃işkenler açısından benzerdi. Hem risperidon hem de paliperidon grubunda 4 hafta sonrasında ortalama serum prolaktin düzeyleri anlamlı olarak artmıştı $(p<0.001)$. Risperidon ve paliperidon grubunda menstrual düzensizlikler, galaktore ve cinsel disfonksiyona bag̃lı olarak ilaç kesilme oranları sırasıyla \%11.9 ve \%30.6 idi ve bu oran paliperidon grubunda istatiksel olarak fazlaydı $\left(\chi^{2}=4.13\right.$, $p=0.04$ ).

Tartıșma: Paliperidonun faydaları ve risperidona bazı üstünlüklerinin olmasına rag̃men, hiperprolaktinemi ve ilişkili belirtiler açısından paliperidonun risperidona göre avantajı olmadıg̃ını düșünüyoruz. Ayrıca kadın hastaların paliperidon ile tedavi edildikleri zaman, hiperprolaktinemi ve ilişkili belirtiler açısından düzenli bir șekilde takip edilmesi gerektig̃ini önermekteyiz. Bilgimize göre, bu çalıșma Türkiye'de risperidon ve paliperidonun serum prolaktin düzeyleri üzerine etkilerini karşılaștıran ve gösteren ilk çalışmadır. Paliperidonun serum prolaktin düzeyi üzerine uzun ve kısa dönem etkilerini aydınlatacak daha ileri ve geniş örneklemli çalıșmalara ihtiyaç bulunmaktadır.

Anahtar sözcükler: risperidon, paliperidon, prolaktin

Journal of Mood Disorders 2014;4(1):7-13

\section{ABSTRACT:}

Comparison of short term effects of risperidone and paliperidone on serum prolactin levels in female patients

objective: Hyperprolactinemia is an adverse effect, which is related with the use of antipsychotics. All typical antipsychotics are considered to increase serum prolactin levels. Compared with typical antipsychotics, most of the atypical antipsychotics have a reduced tendency for increasing serum prolactin levels. However, effects of all atypical antipsychotics on serum prolactin levels are not always similar. In the present study, we aimed to compare short-term effects of risperidone and paliperidone, which are two similar atypical antipsychotics in terms of hyperprolactinemia and its associated symptoms.

Methods: In this study, we screened data of female patients with diagnosis of schizophrenia and other psychotic disorders, bipolar disorder and who were treated with risperidone or paliperidone. The patients who had adequate sociodemographical and clinical data and who had screened in terms of prolactin levels before and fourth week of the treatment were included to study.

Results: Forty-two patients have been treated with risperidone and 36 patients have been treated with paliperidone. Treatment groups were similar in terms of sociodemographic variables. The mean values of serum prolactin levels were significantly increased after four weeks of treatment in both groups $(p<0.001)$. The discontinuation rates because of menstrual irregularities, galactorrhea, sexual dysfunction in risperidone and paliperidone groups were $11.9 \%$ and $30.6 \%$ respectively, and the rate was significantly higher in paliperidone group $\left(\chi^{2}=4.13, p=0.04\right)$. Conclusion: We suggest that beside its benefits and some superiorities compared to risperidone, paliperidone has no advantage over risperidone in terms of hyperprolactinemia and its associated symptoms. We also suggest that female patients should be monitorized regulary in terms of hyperprolactinemia and its associated symptoms while they are being treated with paliperidone. To our knowledge, the present study is the first to compare and demonstrate the effects of paliperidone and risperidone on serum prolactin levels in Turkey. Further studies with larger sample size are needed to highlight the short term and long term effects of paliperidone on serum prolactin levels in female patients.

Key words: risperidone, paliperidone, prolactin

Journal of Mood Disorders 2014;4(1):7-13
${ }^{1} \mathrm{MD}$, Namık Kemal University, Medical Faculty, Department of Psychiatry, Tekirdag̃-Turkey

${ }^{2} \mathrm{MD}$, Gölbașı Hasvak State Hospital, Department of Psychiatry, Ankara-Turkey ${ }^{3} \mathrm{MD}$, Akdeniz University Medical Faculty,
Deplartment Department of Psychiatry, Antalya-Turkey

Yazıșma Adresi / Address reprint requests to: Yrd. Doç. Dr. Yakup Albayrak, Namık Kemal Üniversitesi Tıp Fakültesi, Psikiyatri Anabilimdalı, 59100, Tekirdag̃-Türkiye

Telefon / Phone: +90-505-635-5434

Elektronik posta adresi / E-mail address: dr.fuge@hotmail.com

Kabul tarihi / Date of acceptance: 11 Aralık 2013 / December 11, 2013

Bag̃ıntı beyanı

Y.A., C.U., M.B., M.K.: Yazarlar bu makale ile ilgili olarak herhangi bir çıkar çatıșması bildirmemișlerdir.

Declaration of interest:

Y.A., C.U., M.B., M.K.: The authors reported no conflict of interest related to this article. 


\section{INTRODUCTION}

Prolactin is one of the polypeptide hormones, which is excreted by the lactotroph cells that are located in the anterior pituitary gland. Prolactin is released in a pulstatil style and its halflife is aproximately 50 minutes. Mechanisms that control the synthesis and release of prolactin from anterior pituitary are complex and are influenced by several endogenous regulatory agents and circadian rhythm. Under normal physiological conditions, the regulation of prolactin release is under the control of dopamine (1).

While elevated serum prolactin levels can be seen during pregnancy and breastfeeding, hyperprolactinemia can be considered as a medical problem in normal conditions because of its acute and chronic clinical consequences. The acute and chronic consequences include menstrual irregularities, galactorrhea, sexual dysfunction (2), an elevated long-term risk of osteoporosis or decreased bone mineral density (3), and also increased risk for the development of pituitary tumors (4). All typical antipsychotics were considered to increase serum prolactin levels by blocking of D2 receptors through tuberoinfundibular dopaminergic pathway (5). After initiation of treatment with conventional antipsychotics, the plasma prolactin level increases on avarage 2 to 10 fold during the first week (6). Compared with typical antipsychotics, most of atypical antipsychotics have a reduced tendency for increasing serum prolactin levels (7). However, effects of atypical antipsychotics on serum prolactin level are not always similar and benign. Among atypical antipsychotics, risperidone is associated with the greatest elevation of serum prolactin levels $(8,9)$.

Paliperidone extended-release (ER) is one of the newer atypical antipsychotic which is the active metabolite of risperidone (9-hydroxyrisperidone) and uses the OROS® technology. This new formulation has a property for minimising drug plasma fluctuations compared with oral immediate-release risperidone and it is useful for eliminating the need for initial dose titration $(10,11)$. The paliperidon may be also considered to have superiority to risperidone in terms of its metabolization; because paliperidone uses the cytochrome (CYP) P450 2D6 pathway minimally in its metabolization compared to risperidone $(12,13)$. Thus, paliperidone ER can be considered as safer than risperidone while it is used with other drugs which are metabolized by the CYP P450 2D6
(14). Regarding the disstressfull acute effects of hyperprolactinemia in female patients, we aimed to investigate the acute effects of paliperidone and risperidone on serum prolactin levels and its clinical consequences in female patients.

\section{MATERIALS AND METHODS}

\section{Participants and Procedure}

This study is a retrospective chart-review study. We screened data of patients who admitted to psychiatry units of Kırklareli State Hospital and Gölbaşı State Hospital between dates of January 2011- January 2013 via medical records. We included female patients with diagnosis of schizophreniaandotherpsychoticdisorders(schizoaffective disorders, delusional disorder, etc.) and bipolar disorder according to the diagnostic criteria of American Psychiatric Association's Diagnostic and Statistical Manual of Mental Disorders (DSM-IV-TR) and who were treated with risperidone or paliperidone (15). The sociodemographic data collected from each patients included age, marrital status, employement status, economic status and living place. The clinical data included the diagnosis of patients, dosages of paliperidone and risperidone, history of menstrual irregularities, galactorrhea, sexual dysfunction and serum prolactin level which were determined by radioimmuno assay (RIA) before treatment and four weeks after treatment. Firstly, we have collected 209 women patients who were on the treatments of either risperidone or paliperidone. However, 45 patients were excluded because they had no assessment in terms of serum prolactin level, 46 patients were excluded because they were not drug free at first assessment, 30 patients were excluded because they were given combination of antipsychotics or mood stabilizers and 10 patients were excluded because of insufficent data and comorbid medical illnesses. Finally we could include 42 patients who were on the treatment of risperidone and 36 patients who have been treated with paliperidone. All patients were on either risperidone or paliperidone monotherapy.

\section{Statistical Methods}

Data were analyzed with using the Statistical Package for the Social Sciences-PC version 16.0 (SPSS, Chicago, 
IL). A confidence interval (CI) of $95 \%$ and a 2 -tailed P value less than 0.05 were accepted to be statistically significant for all analyses. Levene test was used for testing the homogeneity of variance of variables. All numerical variables were tested by the Kolmogorov-Smirnov test for normality of distribution. Difference between groups for age was tested with independent sample t-tests, whereas differences in, diagnosis, marrital status, employement status, economic status, living place and history of discontinuation because of menstrual irregularities, galactorrhea, sexual dysfunction etc. by a chi square test Because the distrubution of serum prolactin levels were not parametric, Wilcoxon test was used for assessing changes in the values of serum prolactin before and four weeks after treatment.

\section{RESULTS}

According to our data, 42 patients have been treated with risperidone and 36 patients have been treated with paliperidone. The mean doses of risperidone and paliperdone were $2.9 \pm 0.7 \mathrm{mg} /$ day and $4.3 \pm 1.2 \mathrm{mg} /$ day respectively. The mean ages of risperidone and paliperidone groups were $33.9 \pm 9.6$, and $33.8 \pm 6.8$ years respectively and groups were statistically similar in terms of age $(\mathrm{t}=-0.046, \mathrm{p}=0.96)$. All participants were female. Groups were also similar in terms of marital status, employement status, education status and smoking status (respectively; $\chi^{2}=1.52, \mathrm{p}=0.16 ; \chi^{2}=0.66, \mathrm{p}=0.27$; $\chi^{2}=8.28, \mathrm{p}=0.08$ and $\chi^{2}=3.57, \mathrm{p}=0.06$ ). All participants were likely to live in rural areas ( $p>0.05$ ). In risperidone group, 26 patients were diagnosed as schizophrenia and other psychotic disorders, 16 patients were diagnosed as bipolar disorder; in paliperidone group 25 patients were diagnosed as schizophrenia and other psychotic disorders, 11 patients were diagnosed as bipolar disorder and there was no significant difference between groups in terms of diagnosis (Table 1).

The mean of initial serum prolactin level in risperidone group $14.8 \mathrm{ng} / \mathrm{dl}(4.5-54.9 \mathrm{ng} / \mathrm{dl})$ and the mean level measured at fourth week of the treatment was $27.5 \mathrm{ng} / \mathrm{dl}(11-150 \mathrm{ng} / \mathrm{dl})$. There was a significant increase of serum prolactin level after four week ( $\mathrm{Z}=$ $4.29, \mathrm{p}<0.001)$. The mean value of initial serum prolactin

Table 1: Socidemographic and clinical characteristics of participants

\begin{tabular}{|c|c|c|c|c|}
\hline Variables & Subgroups/Answers & $\begin{array}{l}\text { Risperidone } \\
\quad(n=42)\end{array}$ & $\begin{array}{l}\text { Paliperidone } \\
(n=36)\end{array}$ & Statistic \\
\hline Age (years) & & $33.9 \pm 9.6$ & $33.8 \pm 6.8$ & $t=-0.046 ; p=0.96$ \\
\hline Dosage (mg/day) & & $2.9 \pm 0.7$ & $4.3 \pm 1.2$ & \\
\hline \multirow[t]{3}{*}{ Employement status } & & & & $\chi^{2}=0.66 ; p=0.16$ \\
\hline & Works regulary & $19(45.2 \%)$ & $19(36.1 \%)$ & \\
\hline & Unemployer & $23(54.8 . \%)$ & $23(63.9 \%)$ & \\
\hline \multirow[t]{3}{*}{ Marital status } & & & & $\chi^{2}=1.52 ; p=0.16$ \\
\hline & Single & $26(61.9 \%)$ & $27(25 \%)$ & \\
\hline & Married & $16(38.1 \%)$ & $9(75 \%)$ & \\
\hline \multirow[t]{4}{*}{ Education } & & & & $\chi^{2}=8.28 ; p=0.08$ \\
\hline & $0-7$ years & $7(16.7 \%)$ & $12(4.3 \%)$ & \\
\hline & $7-11$ years & $17(40.5 \%)$ & $12(33.3 \%)$ & \\
\hline & Above 11 years & $18(42.8 \%)$ & $12(33.3 \%)$ & \\
\hline \multirow[t]{3}{*}{ Living Place } & & & & $\chi^{2}=0.16 ; p=0.44$ \\
\hline & Rural & $31(73.8 \%)$ & $28(33.3 \%)$ & \\
\hline & Urban & $11(26.2 \%)$ & $8(22.2 \%)$ & \\
\hline \multirow[t]{3}{*}{ Smoking } & & & & $\chi^{2}=3.57 ; p=0.06$ \\
\hline & Yes & $27(64.3 \%)$ & $30(43.5 \%)$ & \\
\hline & No & $15(35.7 \%)$ & $6(56.5 \%)$ & \\
\hline \multirow[t]{3}{*}{ Discontination } & & & & $\chi^{2}=4.13 ; \mathbf{p}=\mathbf{0 . 0 4}$ \\
\hline & Yes & $5(11.9 \%)$ & $11(30.6 \%)$ & \\
\hline & No & $37(88.1 \%)$ & $17(69.4 \%)$ & \\
\hline \multirow[t]{3}{*}{ Diagnosis } & & & & $\chi^{2}=0.48 ; p=0.32$ \\
\hline & Psychosis & $26(61.9 \%)$ & $25(69.4 \%)$ & \\
\hline & $\mathrm{BD}$ & $16(38.1 \%)$ & $11(30.6 \%)$ & \\
\hline
\end{tabular}

Psychosis: Schizophrenia and other psychotic disorders, BD: Bipolar Disorder. Significant p values predicted in bold character. 
Table 2: Baseline and fourth week prolactin levels of participants

\begin{tabular}{lccc} 
Prolactin Levels & Before Treatment & Fourth Week & Statistic \\
\hline Risperidone & $14.8(4.5-54.9)$ & $27.5(11-150)$ & $Z=-4.29, \mathbf{p}<\mathbf{0 . 0 0 1}$ \\
Paliperidone & $21(11-29)$ & $68.5(16-139)$ & $Z=-5.23, \mathbf{p}<\mathbf{0 . 0 0 1}$
\end{tabular}

Significant $p$ values predicted in bold character

level in paliperidone group $21 \mathrm{ng} / \mathrm{dl}$ (11-29) and the mean level measured at fourth week was $68.5 \mathrm{ng} / \mathrm{dl}$ (16139). There was a significant increase of serum prolactin level after four week $(\mathrm{Z}=-5.23, \mathrm{p}<0.001)$ (Table 2). The discontinuation rates after four weeks because of menstrual irregularities, galactorrhea, sexual dysfunction in risperidone and paliperdone groups were $\% 11.9$ and $30.6 \%$, respectively and the rate was significantly higher in paliperidone group $\left(\chi^{2}=4.13\right.$, $\mathrm{p}=0.04)$ (Table 1).

\section{DISCUSSION}

Hyperprolactinemia is one of the major adverse effects of antipsychotics. Since atypical antipsychotics were introduced to the treatment of schizophrenia, other psychotic disorders and bipolar disorder, they have been considered to have superiority compared to typical antipsychotics in terms of ameliorating cognitive and negative symptoms and having lesser extrapyramidal symptoms and endocrinological side effects $(8,9)$. All typical antipsychotics are considered to increase serum prolactin levels via their D2 blockadge on tuberoinfindubular dopamine pathway. Furthermore, it has been suggested that higher levels of serum prolactin level indicate the efficacy of antipsychotic agents (16). Compared with typical antipsychotics, atypical antipsychotics have reduced tendency to increase serum prolactin levels, altough its exact mechanism is still unclear. It might be related with the combination of D2 and 5-hydroxityriptamin (5HT2) antagonism, which provides atypical antipsychotics relative selectivity for the mesolimbic dopaminergic pathway. Altough the incidence of hyperprolactinemia is considered to be lower than typical antipsychotics, recognizable variations are seen among atypical antipsychotics in terms of causing hyperprolactinemia (17).

Altough risperidone is one of the atypical antipsychotic agent, hyperprolactinaemia can be seen commonly in patients who recieved risperidone treatment. The usage of risperidone is common in various psychiatric disorders; such as it is used in the treatment of schizophrenia and other psychotic disorders, bipolar disorders, symptomatic treatment of aggression in patients with mental retardation, Tourette Syndrome and autism. Risperidone acts as an antagonist on serotonin and dopamine receptors in a dose dependent manner. The affinities of risperidone to serotonin 5-HT2 receptors and to dopamine D2 receptors are relatively higher than its other atypical counterparts (18). 9-hydroxy risperidone, which is the active metabolite of risperidone, is suggested to be more related for devoloping hyperprolactinaemia $(19,20)$. Risperidone has been considered to increase serum prolactin levels more than other atypical agents. This may be due to greater D2 receptor occupancy on the pituitary compared with the striatum. The incidence of side effects, which is relatively related to hyperprolactinemia such as; menstrual irregularites, galactorrhoea, sexual dysfunction amenorrhoea and gynaecomastia during treatment with risperidone, is suggested as approximately $1-10 \%$ (18). While recieving the treatment of risperidone, serum prolactin levels can elevate within a few hours and remain for a relatively long period such as 54 weeks $(18,20,21)$. The data about comparison of hyperprolactinemia during treament with typical antipsychotics and risperidone is conflicting. In two researchs, risperidone was found to be related with higher levels of serum prolactin $(22,23)$, while there were evidences for typical antipsychotics in terms of higher elevation of prolactin compared with risperidone (24). David et al. reported a moderate elevation in serum prolactin concentration during olanzapine treatment (1-4 $\mathrm{ng} / \mathrm{ml})$, intermediate increase during haloperidol treatment $(17 \mathrm{ng} / \mathrm{ml})$ and high elevation for patients who were treated with risperidone $(45-80 \mathrm{ng} / \mathrm{ml})$. Furthermore, in risperidone and haloperidol groups, the mean elevation of prolactin level was reported to be 
higher in female patients (25).

Due to its pharmacological profile as a dopamine D2-receptor antagonist, paliperidone ER was found to elevate mean serum prolactin levels to upper than the normal limit in the 6-week studies (26-28). The levels of serum prolactin were commonly elevated much more in female patients compared with males, remained higher during treatment, and elevated with higher doses of paliperidone ER. From the studies of acute treatment, prolactin-associated side effects were reported in approximately $1 \%-2 \%$ of paliperidone ER or placebo groups (29). In these studies, impotence, other sexual dysfunction, galactorrhoea, amenorrhoea, gynaecomastia or menstrual irregularity were included; however no treatment discontinuation was reported due to these side effects (30). During the 52-week open-label study, significant prolactin-associated side effects were lower than $1 \%$ in all subgroups with the exception of amenorrhea ( $4 \%$ of females in each subgroup), irregular menstruation ( $5 \%$ of female patients in the subgroup initially randomized to receive placebo) and erectile dysfunction (3\% of male patients in the subgroup originally randomized to be treated with olanzapine) (31). Direct comparison between paliperidone ER and risperidone in terms of prolactin elevation is still limited. Melkersson investigated the role of risperidone and its active metabolite paliperidone on prolactin elevation and reported that increased serum prolactin levels were positively correlated with serum paliperidone concentrations but not with the serum concentration of its parent compound risperidone (32). Therefore, this study suggests that paliperidone may be more important than risperidone in contributing to increased serum prolactin levels. Knegtering et al. also reported similar results, suggesting that paliperidone plays a predominant role in prolactin (33). Suzuki et al. also reported increased serum prolactin levels switching from risperidone to paliperidone treatment in elderly in their recent study (34). However, Montalvo et al. reported a signifcant decrease in patients who switched to paliperidone palmitate from long acting injectable risperidone (35). In a very recent meta-analysis, Leucht et al. reported that paliperidone and risperidone had the greatest tendency for elevation of serum prolactin levels (36). Our results are consistent with the investigations that reported increased serum prolactin level in patients who were treated with paliperidone. However, discontinuation rates because of menstrual irregularities, galactorrhea, sexual dysfunction in patients who received paliperidone treatment were significantly higher compared with risperidone group and reported rates from previous studies. We can not exactly explain this higher discontination rates; however we suggest that it might be associated with our small sample size. As the potency to stimulate prolactin secretion is comparable between risperidone and its metabolite, this effect has been related to the higher plasma levels of paliperidone, to its lower brain-to-plasma ratio and longer half-life compared to risperidone.

Present study has some limitations. We suggest that our major limitation is the retrospective design of our study. To reach stronger evidence for comparing the effects of paliperidone and risperidone on serum prolactin levels and associated symptoms, further and proscpective studies are needed. We could not give information about the menstruel period of patients, rating scales for measuring remission and side effects of patients and the kind of isotrop of serum prolactin because of retrospective design of study. We also could not take "Institutional Review Board Approval" for present study because of the retrospective design of our study. The small study sample and variations of diagnosis are other limitations of the present study. We only included female gender because of study design, it might be also considered as another limitiation.

In conclusion, we suggest that beside its benefits and some superiorties of paliperidone to risperidone, paliperidone might have no advantage over risperidone in terms of hyperprolactinemia and its associated symptoms. We also suggest that female patients should be monitorized regulary in terms of hyperprolactinemia and its associated symptoms while they are treated with paliperidone. To our knowledge, the present study is the first to compare effects of paliperidone and risperidone on serum prolactin levels in Turkey. Further studies with larger sample sizes are needed to highlight the short term and long term effects of paliperidone on serum prolactin levels. 


\section{References:}

1. Yen S, Jaffe R. Reproductive Endocrinology. Third ed. WB Saunders, 1991; Philedelphia.

2. HaddadPM, WieckA.Antipsychotic-induced hyperprolactinaemia: mechanisms, clinical features and management. Drugs. 2004;64:2291-314

3. Montejo AL. Prolactin awareness: an essential consideration for physical health in schizophrenia. Eur Neuropsychopharmacol. 2008;18:108-14.

4. Szarfman A, Tonning JM, Levine JG, Doraiswamy PM. Atypical antipsychotics and pituitary tumors: a pharmacovigilance study. Pharmacotherapy. 2006;26:748-58.

5. Knegtering $\mathrm{H}$, van der Moolen AE, Castelein S, Kluiter $\mathrm{H}$, van den Bosch RJ. What are the effects of antipsychotics on sexual dysfunctions and endocrine functioning? Psychoneuroendocrinology. 2003;28:109-23.

6. La Torre D, Falorni A. Pharmacological causesof hyperprolactinemia. Ther Clin Risk Manag. 2007;3:929-51.

7. Cookson J, Hodgson R, Wildgust HJ. Prolactin, hyperprolactinaemia and antipsychotic treatment: a review and lessons for treatment of early psychosis. J Psychopharmacol. 2012;26:42-51.

8. Perkins DO. Antipsychotic-induced hyperprolactinemia: Pathophisology and clinical consequences. Adv Stud Med. 2004;4:982-6.

9. Komossa K, Rummel-Kluge C, Schwarz S, Schmid F, Hunger $\mathrm{H}$, Kissling W, Leucht S. Risperidone versus other atypical antipsychotics for schizophrenia. Cochrane Database Syst Rev. 2011 Jan 19;(1):CD006626.

10. Conley R, Gupta SK, Sathyan G. Clinical spectrum of the osmotic controlled release oral delivery system (OROS), an advanced oral delivery form. Curr Med Res Opin. 2006;22:1879-92.

11. Berwaerts J, Cleton A, Rossenu S, Talluri K, Remmerie B, Janssens L, Boom S, Kramer M, Eerdekens M. A comparison of serum prolactin concentrations after administration of paliperidone extended-release and risperidone tablets in patients with schizophrenia. J Psychopharmacol. 2010;24:1011-8.

12. Berwaerts J, Cleton A, Herben V, van de Vliet I, Chang I, van Hoek $P$, Eerdekens M: The effects of paroxetine on the pharmacokinetics of paliperidone extended-release tablets. Pharmacopsychiatry. 2009;42:158-63.

13. Vermeir M, Boom S, Naessens I, Talluri K, Eerdekens $M$ : Absorption, metabolism and excretion of a single oral dose of 1 mg paliperidone ina population of five healthy male subjects. Eur Neuropsychopharmacol. 2005; 15:S648.

14. Chwieduk CM, Keating GM. Paliperidone extended release: a review of its use in the management of schizophrenia. Drugs. 2010;10:1295-317.

15. American Psychiatric Assosiation Diagnostic and Statistical Manual of Mental Disorders, $4^{\text {th }}$ ed., text revsion. Washington DC: American Psychiatric Assosiation. 2000.

16. Hummer M, Huber J. Hyperprolactinaemia and antipsychotic therapy in schizophrenia. Curr Med Res Opin. 2004;20:189-97.
17. Hamner M. The effects of atypical antipsychotics on serum prolactin levels. Ann Clin Psychiatry. 2002;14:163-73.

18. Madhusoodanan S, Parida S, Jimenez C. Hyperprolactinemia associated with psychotropics-a review. Hum Psychopharmacol. 2010;25:281-97.

19. Knegtering R, Baselmans P, Castelein S, Bosker F, Bruggeman R, van den Bosch RJ. Predominant role of the 9-hydroxy metabolite of risperidone in elevating blood prolactin levels. Am J Psychiatry. 2005;162:1010-2.

20. Tollefson GD, Beasley CM Jr, Tran PV, Street JS, Krueger JA, Tamura RN, Graffeo KA, Thieme ME. Olanzapine versus haloperidol in the treatment of schizophrenia and schizoaffective and schizophreniform disorders: results of an international collaborative trial. Am J Psychiatry. 1997;154:457-65.

21. Purdon SE, Jones BD, Stip E, Labelle A, Addington D, David SR, Breier A, Tollefson GD. Neuropsychological change in early phase schizophrenia during 12 months of treatment with olanzapine, risperidone, or haloperidol. The Canadian Collaborative Group for research in schizophrenia. Arch Gen Psychiatry. 2000;57:249-58.

22. Kleinberg DL, Davis JM, de Coster R, Van Baelen B, Brecher M. Prolactin levels and adverse events in patients treated with risperidone. J Clin Psychopharmacol. 1999;19:57-61.

23. Kinon BJ, Stauffer VL, McGuire HC, Kaiser CJ, Dickson RA, Kennedy JS. The effects of antipsychotic drug treatment on prolactin concentrations in elderly patients. J Am Med Dir Assoc. 2003;4:189-94

24. Kearns AE, Goff DC, Hayden DL, Daniels GH. Risperidoneassociated hyperprolactinemia. Endocr Pract. 2000;6:425-9.

25. David SR, Taylor CC, Kinon BJ, Breier A. The effects of olanzapine, risperidone and haloperidol on plasma prolactin levels in patients with schizophrenia. Clin Ther. 2000;22:1085-96.

26. Kane J, Canas F, Kramer M, Ford L, Gassman-Mayer C, Lim P, Eerdekens M. Treatment of schizophrenia with paliperidone extended-release tablets: a 6-week placebo-controlled trial. Schizophrenia Research. 2007;90:147-61.

27. Davidson M, Emsley R, Kramer M, Ford L, Pan G, Lim P, Eerdekens M. Efficacy, safety and early response of paliperidone extendedrelease tablets (paliperidone ER). Results of a 6-week, randomized, placebo-controlled study. Schizophrenia Research. 2007;93:11730 .

28. Marder SR, Kramer M, Ford L, Eerdekens E, Lim P, Eerdekens M, Lowy A. Efficacy and safety of paliperidone extended-release tablets. Results of a 6-week, randomized, placebo-controlled study. Biological Psychiatry. 2007;62:1363-70.

29. Meltzer HY, Bobo WV, Nuamah IF, Lane R, Hough D, Kramer M, Eerdekens M. Efficacy and tolerability of oral paliperidone extended-release tablets in the treatment of acute schizophrenia: pooled data from three 6 -week, placebo-controlled studies. Journal of Clinical Psychiatry. 2008;69:817-29.

30. Chwieduk CM, Keating GM. Paliperidone extended release: a review of its use in the management of schizophrenia. Drugs. 2010;70:1295-317. 
31. Emsley R, Berwaerts J, Eerdekens M, Kramer M, Lane R, Lim P, Hough D, palumbo J. Efficacy and safety of oral paliperidone extended-relaese tablets in the treatment of acute schizophrenia: pooled data from three 52-week open-label studies. International Clinical Psychopharmacology. 2008;23:343-56.

32. Melkersson KI. Prolactin elevation of the antipsychotic risperidone is predominantly related to its 9-hydroxy metabolite. Hum Psychopharmacol. 2006;21:529-32.

33. Knegtering R, Baselmans P, Castelein S, Bosker F, Bruggeman R, van den Bosch RJ. Predominant role of the 9-hydroxy metabolite of risperidone in elevating blood prolactin levels. Am J Psychiatry. 2005;162:1010-2.
34. Suzuki H, Gen K, Otomo M, Inoue Y, Hibino H, Mikami A, Matsumoto H, Mikami K. Study of the efficacy and safety of switching from risperidone to paliperidone in elderly patients with schizophrenia. Psychiatry Clin Neurosci. 2013;67:76-82.

35. Montalvo I, Ortega L, López X, Solé M, Monseny R, Franch J, Vilella E, Labad J. Changes in prolactin levels and sexual function in young psychotic patients after switching from longacting injectable risperidone to paliperidone palmitate. Int Clin Psychopharmacol. 2013;27:46-9.

36. Leucht S, Cipriani A, Spineli L, Mavridis D, Orey D, Richter F, et al. Comparative efficacy and tolerability of 15 antipsychotic drugs in schizophrenia: a multiple-treatments meta-analysis. Lancet. 2013;6736:60733-43 